\title{
Factors Influencing Customers Loyalty Towards Electronic Commerce
}

\author{
Pankaj Misra ${ }^{1}$ and Anjana Pandey ${ }^{2 *}$ \\ 1 Assistant Professor, Department of Hotel Management, Bhagat Phool Singh Mahila Vishwavidyalaya, \\ Khanpur Kalan, Sonepat, Haryana. \\ Email:pankajchefbpsmv@gmail.com \\ ${ }^{2}$ Assistant Professor, Department of Commerce, Bhagat Phool Singh Mahila Vishwavidyalaya, Khanpur Kalan, \\ Sonepat, Haryana. \\ *Email:misra.anjana2015@gmail.com
}

\begin{abstract}
Long term growth of any firm is depends upon profitability. Customer retention and customer loyalty is very important for growth of any firm. The objective of this paper is to identify the factors which influence the customer's loyalty towards business to customer (B2C) electronic commerce (E-Commerce) and mediating effects of customer satisfaction and trust on customer loyalty. The results of the study showed that user interface quality has positive significant effect on customer satisfaction and trust. Information quality has significant effect on customer satisfaction but not on trust. Privacy and security has also not significant towards customer satisfaction but significant to trust. Customer satisfaction and trust are positively related with each other and mediating the customer loyalty with determinants of service quality. Result of regression analysis shows that dependent variable e-commerce loyalty is influenced by e-customer satisfaction and e-trust. It is cleared that electronic customer satisfaction (ECS) and electronic trust (ET) are direct antecedents of electronic customer loyalty (ECL) towards B2C E-Commerce.
\end{abstract}

Keywords: E-Commerce, Customer Loyalty, Customer satisfaction, trust, Service quality.

\section{INTRODUCTION}

Life of human being changes after advent of Industrial revolution and Internet revolution. Industrial revolution changes the manufacturing, Marketing, Production, and Retailing, advertising sectors (Alim, 2019). Internet revolution increase the strength of business as virtual business world referred to as E-Commerce (Wen, et al 2019). ECommerce started in 1995 and now it becomes a part of our daily life. During the period of Covid 19 pandemic digital transformation in terms of consumer behavior is also influenced ( El Junusi, 2020). In the Present Scenario of competition in each field, it is very difficult to get the loyal customer and retain them as loyal as always. Retention of customer loyalty direct affects the profitability and success of business. Presently business focused on retention of existing rather than winning of new customer. E-Loyalty has become an important aspect in e- commerce business after high level competition arises in this field (Chen et al, 2014) and using the period of COVID- 19.
Today customers are very smart and much aware. If their needs were not fulfilled they easily shift or change the company. It is very important from the business point of view that what are the determinants or factors which affected the customer loyalty in ECommerce. Consequently, the objective of this study is to identify the key factors that influence the Indian customers to become them loyal towards B2C ecommerce. Through extant literature review, the study determines user interface quality, product/ service information quality, privacy, and security are indirect determinants or antecedents of customer loyalty towards B2C e-commerce. These objectives help the higher managerial authority of any firms' to work on the right areas and in right ways to increase customer's retention.

This research paper first describes the research objectives for the study. After that, researchers hypothesized relationship between e-commerce customer loyalty with its antecedent, to build a 
conceptual framework for Indian customer loyalty. This is followed by research methodology and the data analysis, testing of hypothesis (whether they are accepted or rejected in the context of Indian customers) and findings.

\subsection{Research Objectives}

1. To identify the E- Service quality as key factors in influencing electronic information satisfaction and trust.

2. To identify customer satisfaction as mediating factor that influencing e-customer loyalty.

3. To identify trust as mediating factor that influencing e-customer loyalty.

4. To identify the relationship between customer satisfaction and trust towards customer loyalty.

\section{THEORETICAL BACKGROUND AND LITERATURE REVIEW}

It is need of the hour for manager of the firm to focusing their efforts on the key and important areas which affects the customer loyalty of their ecommerce business. Manager insight understands the factors affecting the customer loyalty. Some of the glimpses of literature review are as follows:

\subsection{User interface Quality}

Service quality is the most significant determinant of customer loyalty (Parasuraman, et.al, 1988; Aydin and Ozer, 2005; Boohene and Agyapong, 2011). E-Service quality defined by Santos (2003) that customer assessment and judgments of e-service delivery in the virtual market place. Cronin and Taylor (1992) developed Service quality perception model (SERVPERF), a similar measurement as Service Quality Model (SERVQUAL) but consisting only on performance measurement. They stated that perceptions only are a better measurement of service quality as they comprise the expectations too. Similarly in present context many researchers (Janda, et.al.,2002; Yang and Jun, 2002 and Santos, 2003) conceptualized the dimension of e- service quality. E-Service quality dimensions include website design, reliability, responsiveness, trust and personalization. Quality of user interface is directly affected the trust (Gummerus, et.al,2004; Aubert, Benoit. A ,2001). Thus hypothesize:

H1a: Perceived user interface quality (UIQ) has positive and significant effect on e-commerce customer satisfaction (ECS).
H1b: Perceived user interface quality (UIQ) has positive and significant effect on e-commerce trust (ET)

\subsection{E-Commerce service Information Quality}

The purpose of web site content is to converting site traffic into sales. Some website content not provide relevant information which customer's find. Bakos (1997) concluded in the study that primary role of website is to provide relevant information like product information and price related information. This search reduces the search cost of the consumers. Website quality significantly affects trust (McKnight et.al 2002) while informational quality significantly affects on trust for both potential and repeat customers (Kim, et.al, 2004). Thus, we hypothesize:

H2a: Perceived product/service information quality has positive and significant effect on the ecommerce customer satisfaction.

$\mathrm{H} 2 \mathrm{~b}$ : Perceived product/service information quality has positive and significant effect on the ecommerce customer trust.

\subsection{E-Commerce service perceived Security}

Security issue is major obstacles in e-commerce business. Security includes reliability of online payment system after completion of sale procedure (Dong-Her, 2004). A study conducted by Kolsaker and Payne (2002) find out that e-commerce business maintain the security. Warrington, et.al (2000) found in the study that website plays important role to build electronic trust in consumers by decreasing perceived environmental risk or by raising security.

H3a: Perception of security risk has indirect positive effect on e-commerce customer satisfaction.

$\mathrm{H} 3 \mathrm{~b}$ : Perception of security risk has indirect positive effect on e-commerce customer trust

\subsection{E-Commerce service Perceived Privacy}

Privacy is important determinants of customer loyalty of B2C e-commerce customers. Customers trust builds on any $\mathrm{B} 2 \mathrm{C}$ e-commerce business when their private data would be handled properly, if not then trust would not be build (Park and Kim, 2003). The perceived privacy is also important for customer satisfaction of e-commerce websites. Perceived privacy is defined as consumers' "ability to control presence of other people in the environment during a market transaction or consumption behavior and the dissemination of information related to or provided 
during such transactions or behaviors to those who were not present" (Goodwin, 1991).

H4a: Perception of privacy risk has indirect and positive significant effect on e-commerce customer satisfaction.

H4b: Perception of privacy risk has indirect and positive effect on e-commerce trust.

\subsection{E-Commerce service Customer Trust}

Trust is very important determinant of customer loyalty. Customer trust is an important factor of relationship marketing, ongoing process of continuing and maintaining the long lasting relationship (Morgan and Hunt, 1994 and Chaudhuri and Holbrook, 2001). Trust is the most important and significant factors in improving the quality of eservices (Sitorus and Yustisia,2018; Choshin and Ghaffari, 2017). H5: Customer trust has positive and significant effect on customer satisfaction.

\subsection{Customer Satisfaction}

Customer satisfaction influenced consumer's loyalty towards B2C e-commerce (Yazidd, et.al, 2020; Eid, 2011; Eid and Anazi, 2008; Morgan and Hunt, 1994; Anderson, et.al, 1994, Rup et al., 2021).

H6: Customer satisfaction has positive and significant effect on customer trust.

\subsection{Customer Loyalty}

E-Loyalty is depending upon quality customer support, on time delivery, convenient, reasonable shipping price and handling, clear and trustworthy privacy policies (Reichheld and Schefter, 2000). Service quality, customer satisfaction and trust are important and influencing factors of customer loyalty (Yazidd, et.al, 2020; Eid, 2011; Eid and Anazi, 2008; Morgan and Hunt, 1994; Anderson, et.al, 1994; Rup et al., 2018).

H7: customer satisfaction has direct positive effect on the e- commerce customer loyalty.

H8: Customer trust has direct positive effect on the e- commerce customer loyalty.

\section{Research Model and Hypotheses}

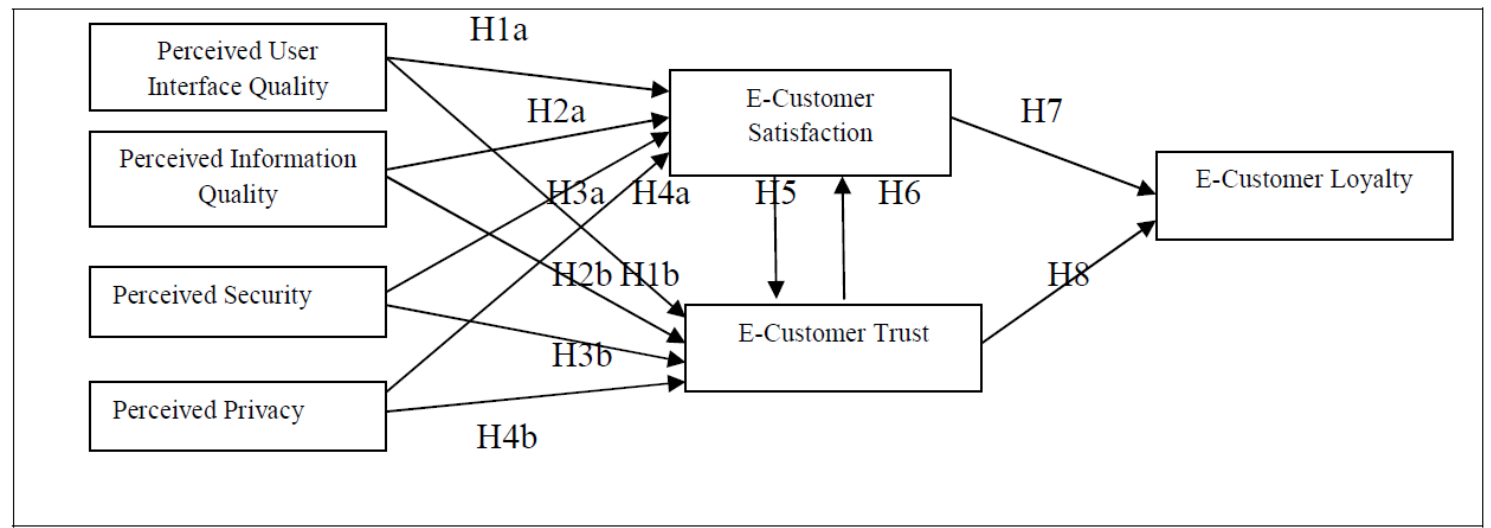

\section{Figure 1: Research Model}

The research model depicted in figure 1 shows two mediating variables influencing e- commerce customer loyalty: E-commerce customer satisfaction and e-commerce customer trust. In order to gain more insights and depth about the factors influencing e- commerce customer loyalty, four factors are identified i.e. User interface quality, information quality, security and privacy. In the proposed research model Indian consumer loyalty towards $\mathrm{B} 2 \mathrm{C}$ e-commerce is hypothesized and personalized to be influenced by Indian consumer experience with e- commerce trust and e-commerce satisfaction.

\section{RESEARCH METHODOLOGY}

A survey was conducted among the Indian Ecustomers and sample was taken from Indian state of Haryana. The questionnaire consisted of three sections. The first section was about profile of the respondents including age, gender, educational qualification, monthly income and occupation. Second section was about the general questions to usage of $\mathrm{B} 2 \mathrm{C}$ E-commerce. The third section is seeking E-customers opinion on the perceived influence of E-loyalty towards B2C E-commerce. 
The questionnaires were distributed in Haryana with the use of convenience sampling technique. 250 questionnaires were distributed and only 190 were received back and only 174 questionnaires were usable and considered in this study.

\section{DATA COLLECTION AND ANALYSIS}

In the study Statistical Package for the Social Sciences (SPSS) for windows was used to entering, cleaning and analysis of the data. Principle Component Factoring Analysis is used to ensure the validity of measures. To validate the appropriateness of the factor analysis, the Kaiser-Meyer-Olkin (KMO) measures (Table.1) sampling adequacy.

Table1: Measure of Sampling Adequacy and Reliability

\begin{tabular}{|l|l|l|}
\hline Construct & Kaiser-Meyer-Olkin Measure & Cronbach's alpha \\
\hline Perceived User Interface Quality (UIQ) & 0.61 & 0.4571 \\
\hline Perceived Information Quality (IQ) & 0.580 & 0.5422 \\
\hline Perceived Privacy (PP) & 0.62 & 0.6630 \\
\hline Perceived Security Risk(PSR) & 0.72 & 0.6082 \\
\hline E-Commerce Customer Satisfaction(ECS) & 0.576 & 0.5853 \\
\hline E-Commerce Trust(ET) & 0.65 & 0.5012 \\
\hline E-Commerce Loyalty (ECL) & 0.72 & 0.6416 \\
\hline
\end{tabular}

\section{Source: Primary Data}

The stepwise Regression analysis method is used to test the hypothesis on the basis of testing the significance of generated values of the $\beta$ coefficients (Table 3).

The demographic profile of the respondents was shown in table 2. Maximum (57.5\%) respondents

Table 2: Demographic Profile were lies in the less than 25 years age group. Male $(63.2 \%)$ respondents were used online shopping and having educational qualification was graduate $(65.6 \%)$. Monthly income of the respondents was lies in the 30001 to 50000. Among all the respondents $71.3 \%$ were employee.

\begin{tabular}{|l|l|l|l|}
\hline Profile & Particulars & Frequency & Percentage \\
\hline \multirow{4}{*}{ Age (in Years) } & Less than 25 & 100 & 57.5 \\
\cline { 2 - 4 } & $25-40$ & 62 & 35.6 \\
\cline { 2 - 4 } & Greater than 40 & 12 & 6.9 \\
\hline \multirow{4}{*}{ Gender } & Male & 110 & 63.2 \\
\cline { 2 - 4 } & Female & 64 & 36.8 \\
\hline \multirow{5}{*}{ Mighest Educational Qualification } & High School & 05 & 2.8 \\
\cline { 2 - 4 } & Intermediate or $12^{\text {th }}$ & 15 & 8.6 \\
\cline { 2 - 4 } & Graduation & 114 & 65.6 \\
\cline { 2 - 4 } & Post Graduation & 35 & 20.2 \\
\cline { 2 - 4 } & Other & 05 & 2.8 \\
\hline & Less than 10000 & 10 & 5.7 \\
\cline { 2 - 4 } & $10000-30000$ & 49 & 28.2 \\
\cline { 2 - 4 } & $30001-50000$ & 90 & 51.7 \\
\cline { 2 - 4 } & More than 50000 & 25 & 14.4 \\
\hline \multirow{5}{*}{ Occupation } & Student & 10 & 5.7 \\
\cline { 2 - 4 } & Employee & 124 & 71.3 \\
\cline { 2 - 4 } & Professionals & 40 & 23.0 \\
\hline
\end{tabular}

Source: Primary Data

This study presents the regression analysis of the service quality factors towards customer loyalty which mediates with customer satisfaction and customer trust. The results of a stepwise regression analysis for testing the hypotheses $\mathrm{H} 1$ to $\mathrm{H} 8$ are shown in Table 3. It is shown in table 3 that user interface quality (UIQ) and Informational quality
(IQ) are positively related to e-commerce customer satisfaction (ECS). The parameter estimates for the $\beta$ coefficients associated with UIQ and IQ $(\beta 1=0.395$ and $\beta 2=0.395)$ are significant. All parameter estimates for the coefficients associated with the predictor are significant at $\mathrm{p}<.05$.Perceived security and perceived privacy are negatively related to e- 
commerce satisfaction $(\beta 3=.030$ and $\beta 4=.081)$. Negative relationship means when the security and privacy risk while using e-commerce applications is decrease than customer satisfaction and e-commerce trust will increases. Value of $\beta$ coefficient associated with PSR and PP are very low, and then the hypotheses $\mathrm{H} 3 \mathrm{a}$ and $\mathrm{H} 4 \mathrm{a}$ are not accepted.

Table 3 depicted that E-commerce Customer Satisfaction (ECS) is positively related with the E-
Commerce trust (ET). $\quad \beta$ coefficient (0.217) of trust is significant. ECS and ET are positively related with each other and customer loyalty (ECL). Results supported the study of Eid,and Anazi, 2008. Result of regression analysis shows that dependent variable e-commerce loyalty is influenced by e-customer satisfaction and e-trust. It is cleared that ECS and ET are direct antecedents of ECL towards B2C ECommerce. Same results were found in Flavian and Guinalýu ,2006 and Eid, and Anazi, 2008).

Table 3: Results

\begin{tabular}{|c|c|c|c|c|c|c|}
\hline Hypothesis & $\begin{array}{l}\text { Independent } \\
\text { Variable }\end{array}$ & Dependent Variable & $\mathbf{R}^{2}$ & $\begin{array}{l}\beta \\
\text { Coefficients } \\
\text { and t-values }\end{array}$ & Sig. & Decision \\
\hline \multicolumn{3}{|c|}{$\begin{array}{l}\text { E-Customer satisfaction }(\mathrm{ECS})=?+\beta 1 \mathrm{UIQ}+\beta 2 \mathrm{IQ}+ \\
\beta 3 \mathrm{PSR}+\beta 4 \mathrm{PP}+\mathrm{e}\end{array}$} & 0.156 & 6.985 & .00 & \\
\hline H1a & UIQ & ECS & & 0.395 & & Accepted \\
\hline $\mathrm{H} 2 \mathrm{a}$ & IQ & ECS & & 0.395 & & Accepted \\
\hline $\mathrm{H} 3 \mathrm{a}$ & PSR & ECS & & -0.030 & & Not Accepted \\
\hline $\mathrm{H} 4 \mathrm{a}$ & PP & ECS & & -0.081 & & Not Accepted \\
\hline \multicolumn{3}{|c|}{ E-Trust $(E T)=?+\beta 1 \mathrm{UIQ}+\beta 2 \mathrm{IQ}+\beta 3 \mathrm{PSR}+\beta 4 \mathrm{PP}+\mathrm{e}$} & 0.153 & 8.091 & .00 & \\
\hline H1b & UIQ & ET & & 0.10 & & Not Supported \\
\hline $\mathrm{H} 2 \mathrm{~b}$ & IQ & ET & & 0.247 & & Accepted \\
\hline $\mathrm{H} 3 \mathrm{~b}$ & PSR & ET & & -0.168 & & Accepted \\
\hline $\mathrm{H} 4 \mathrm{~b}$ & PP & ET & & -0.136 & & Accepted \\
\hline \multicolumn{3}{|c|}{ E-Customer Satisfaction $(\mathrm{ECS})=?+\beta 1 \mathrm{ET}+\mathrm{e}$} & 0.05 & 11.747 & .00 & \\
\hline H5 & ET & ECS & & 0.21 & & Accepted \\
\hline \multicolumn{3}{|c|}{$\mathrm{E}-$ Trust $(\mathrm{ET})=?+\beta 1 \mathrm{ECS}+\mathrm{e}$} & 0.04 & 9.229 & .00 & \\
\hline H6 & ECS & ET & & 0.218 & & Accepted \\
\hline \multicolumn{3}{|c|}{ E-Customer Loyalty $(\mathrm{ECL})=?+\beta 1 \mathrm{ECS}+\beta 2 \mathrm{ET}+\mathrm{e}$} & 0.04 & 7.023 & .00 & \\
\hline $\mathrm{H7}$ & ECS & ECL & & 0.125 & & Accepted \\
\hline $\mathrm{H} 8$ & ET & ECL & & 0.121 & & Accepted \\
\hline
\end{tabular}

\section{Source: Primary Data}

\section{MANAGERIAL AND PRACTICAL IMPLICATIONS}

In the competitive environment in the field of online shopping, it will be required to online business marketers to build the customers and also retain them with the development of loyalty among them. They refine their marketing strategies and decision to attract and retain the customers. These studies help and guide them to identify the factors affecting customer loyalty and developed policies accordingly. As the customers have various options in the market so all the factors are important and required expert strategies to look and make them effective. Service quality consists of website designing, correct information, privacy, and security. Each must be done by trained staff so the implementation will be well and fruitful. Vision of company will be cooperating with the staff, policy and technology.

\section{CONCLUSIONS}

The identified key factors affecting E-Commerce customer loyalty are: user interface quality, product/ service Informational quality, security perception and privacy perception were found to have significant effects on Indian customer satisfaction and E-customer trust. It was also investigated in the study that e-commerce customer satisfaction and ecommerce trust plays significant mediation role on ecommerce customer loyalty towards $\mathrm{B} 2 \mathrm{C}$ commerce retailers. Information quality variable of e-commerce website was important factors which influence the ecommerce customer loyalty in terms of $\mathrm{B} 2 \mathrm{C}$ ecommerce applications. In the research it was found that adoption of B2C E-Commerce was used higher among older, educated and high income class. This 
research is good for e-retailer in terms of focus areas, but this study has various limitations.

\section{LIMITATIONS AND SCOPE FOR FURTHER STUDY}

The sample has geographical constraints. Samples were taken only from India (Haryana) and sample size was not large enough. Therefore, a more representative sample selection and larger sample size ill increase the validity of the study. The study was only focuses on some variable only there may be chances to cover more variable in the study to investigate the factors influencing e-commerce customer loyalty in B2C E-Commerce. Further study may be including more states of India, more samples size and more variable. E-Service quality may be included more aspects like reliability, payment options and the security issues and more important factor which is return facility if the product will be defective or not up to the mark or any other reasons.

\section{REFERENCES}

[1] Alim, Liiban. "The Impact of Industrial Revolution to Marketing." Electronic Research Journal of Social Sciences and Humanities, vol.1, no. IV , 2019,pp. 114-122.

[2] Anderson, Eugene W, et al. "Customer Satisfaction, Market Share, and Profitability: Findings from Sweden." Journal of marketing, vol. 58, no.3, 1994, pp. 5366.https://doi.org/10.1177\%2F00222429940580 0304

[3] Aubert, Benoit A. "The impact of interface quality on trust in web retailers." Cahier $d u$ GReSI no 1.05 (2001).Internet research: Electronic networking applications and policy, 11(5), 388 398.https://doi.org/10.1108/1066224011041016 5.

[4] Aydin, Serkan, and Gökhan Özer. "The analysis of antecedents of customer loyalty in the Turkish mobile telecommunication market." European Journal of marketing,vol. 39, no. 7/8, 2005, pp 910-925. https://doi.org/10.1108/03090560510601833.

[5] Bakos, J. Yannis. "Reducing buyer search costs: Implications for electronic marketplaces." Management science, vol. 43, no. 12, 1997, pp. 1676-1692. https://www.jstor.org/stable/2634535.
[6] Boohene, Rosemond, and Gloria KQ Agyapong. "Analysis of the antecedents of customer loyalty of telecommunication industry in Ghana: The case of Vodafone (Ghana)." International Business Research,vol.4, no.1, 2011 pp. 229-240. http://citeseerx.ist.psu.edu/viewdoc/download?d oi $=10.1 .1 .662 .3208 \&$ rep $=$ rep $1 \&$ type $=$ pdf

[7] Chaudhuri, Arjun, and Morris B. Holbrook. "The chain of effects from brand trust and brand affect to brand performance: the role of brand loyalty." Journal of marketing, vol. 65, no.2, 2001, pp. 81-93.

[8] Chen, Jengchung et al. "E-commerce web site loyalty: A cross cultural comparison." Information Systems Frontiers, vol. 17, no. 6 ,2015, pp. 1283-1299.

[9] Choshin, Mahdi, and Ali Ghaffari. "An investigation of the impact of effective factors on the success of e-commerce in small-and medium-sized companies." Computers in Human Behavior, vol. 66, 2017, pp. 67-74.

[10] Cronin Jr, J. Joseph, and Steven A. Taylor. "Measuring service quality: a reexamination and extension." Journal of marketing, vol.56, no. 3, 1992, pp. 55-68. https://doi.org/10.1177\%2F0022242992056003 04

[11] Dong-Her, Shih, et al. "Internet security: malicious e-mails detection and protection." Industrial Management \& Data Systems, vol.104, no.7,2004, pp.613623.https://doi.org/10.1108/0263557041055027

[12] Eid, Mustafa I. "Determinants of e-commerce customer satisfaction, trust, and loyalty in Saudi Arabia." Journal of electronic commerce research, vol. 12, no.1, 2011, pp. 78-93.

[13] Eid, Mustafa, and Fahad Ubaid Al-Anazi. "Factors influencing Saudi consumers loyalty toward B2C E-commerce." AMCIS 2008 Proceedings, 2008, pp.1-10. http://aisel.aisnet.org/amcis2008/405.

[14] El Junusi, Rahman. “ Digital Marketing During the Pandemic Period; A Study of Islamic Perspective".. Journal of Digital Marketing and Halal Industry, vol 2, no. 1,2020, pp. 15-28. http://dx.doi.org/10.21580/jdmhi.2020.2.1.5717 
[15] Goodwin, Cathy. "Privacy: Recognition of a consumer right." Journal of Public Policy \& Marketing, vol.10, no.1 ,1991, pp. 149166.https://www.jstor.org/stable/30000257

[16] Gummerus, Johanna, et al. "Customer loyalty to content-based Web sites: the case of an online health-care service." Journal of services Marketing,vol. 18, no. 3, 2004, pp. 175-186. http://dx.doi.org/10.1108/08876040410536486

[17] Janda, Swinder,et al. . "Consumer perceptions of Internet retail service quality." International journal of service industry management,13,no. 5,2002 , $\mathrm{pp}$ $412-$ 431.https://doi.org/10.1108/0956423021044791 3

[18] Kim, Hee-Woong,et al. "A comparison of online trust building factors between potential customers and repeat customers." Journal of the association for information systems, vol.5, no.10,2004, pp.392-420.

[19] Kolsaker, Ailsa, and Claire Payne. "Engendering trust in e-commerce: a study of gender-based concerns." Marketing intelligence \& planning, vol 20, no 4, 2002, pp. 206-214. https://doi.org/10.1108/02634500210431595

[20] McKnight, D. Harrison, Vivek et al. "The impact of initial consumer trust on intentions to transact with a web site: a trust building model." The journal of strategic information systems, vol. 11, no.3-4, 2002, pp. 297-323.

[21] Morgan, Robert M., and Shelby D. Hunt. "The commitment-trust theory of relationship marketing." Journal of marketing, vol.58, no. 3, 1994, pp.

20 38.https://www.jstor.org/stable/1252308.

[22] Oliver, Richard L. "Whence consumer loyalty?." Journal of marketing, vol. 63, 1999, pp. 33-44.https://www.jstor.org/stable/1252099.

[23] Parasuraman, Ananthanarayanan,et al. "Servqual: A multiple-item scale for measuring consumer perc." Journal of retailing, vol. 64 , no 1,1988, pp. 12.

[24] Park, Chung-Hoon, and Young-Gul Kim. "Identifying key factors affecting consumer purchase behavior in an online shopping context." International journal of retail \& distribution management, vol. 31, no. 1, 2003, pp. 16-29. DOI 10.1108/09590550310457818.
[25] Reichheld, Frederick. F., and Phil Schefter. "Eloyalty: your secret weapon on the web." Harvard business review,vol.78, no.4, 2000, pp. 105-113.

[25] Rosenberg, Larry J., and John A. Czepiel. "A marketing approach for customer retention." Journal of consumer marketing, vol.1, no. 2, 1984, pp. 4551.https://doi.org/10.1108/eb008094.

[26] Santos, Jessica. "E-service quality: a model of virtual service quality dimensions." Managing Service Quality: An International Journal, vol. 13, no. 3, 2003, pp. 233-246. https://doi.org/10.1108/09604520310476490.

[27] Sitorus, Tigor, and Milawati Yustisia. "The influence of service quality and customer trust towards customer loyalty: the role of customer satisfaction." International Journal for Quality Research, vol.12, no 3, 2018, pp. 639-653. DOI - 10.18421/IJQR12.03-06.

[28] Warrington, Traci B., and Helen M. Caldwell. "Building trust to develop competitive advantage in e-business relationships." Competitiveness Review: An International Business Journal, vol.10, no.2, 2000 , pp.160168.https://doi.org/10.1108/eb046409.

[29] Wen, Lizhi, and H. A. Guy. "Factors and Barriers to Adoption of E-Commerce: The Case of Developing Countries." J Entrepren Organiz Manag, vol. 8, no, 1, 2019, pp 1-5. DOI: 10.4172/2169-026X.1000265

[30] Yang, Zhilin, and Minjoon Jun. "Consumer perception of e-service quality: From Internet purchaser and non-purchaser perspectives." Journal of Business Strategies, vol. 25, no. 2, 2008, pp. 59-84.

[31] Yazid, Ahmad Shukri, et al. "The Effect of Corporate Image on Customer Loyalty: The Mediating Effect of Customer Satisfaction." The Journal of Research on the Lepidoptera, vol.51, no. 2, 2020, pp.124-138. DOI: 10.36872/LEPI/V51I2/301083.

[32] B.K., Rup, J. Gochhayat, S. Samanta, Revisiting Brand Personality Attributes: Mediating Role of Brand Attitude. International Journal of Asian Business and Information Management (IJABIM) 12(2) (2021) 124-136. http://doi.org/10.4018/IJABIM.20210401.oa8 
[33] B.K., Rup, J. Gochhayat, S. Samanta, Role of Biological Sex and Gender Roles on Perceived Brand Personality, International Journal of Knowledge-based and Intelligent Engineering $\begin{array}{lllll}\text { Systems } & 22 & \text { (4) (2018) 231-237. }\end{array}$ DOI: $10.3233 /$ KES-180387 